\title{
Epstein-Barr Virus and Gastric Cancer Risk: A Meta- analysis With Meta-regression of Case-control Studies
}

\author{
Jong-Myon Bae, Eun Hee Kim \\ Department of Preventive Medicine, Jeju National University School of Medicine, Jeju, Korea
}

Objectives: Research on how the risk of gastric cancer increases with Epstein-Barr virus (EBV) infection is lacking. In a systematic review that investigated studies published until September 2014, the authors did not calculate the summary odds ratio (SOR) due to heterogeneity across studies. Therefore, we include here additional studies published until October 2015 and conduct a meta-analysis with meta-regression that controls for the heterogeneity among studies.

Methods: Using the studies selected in the previously published systematic review, we formulated lists of references, cited articles, and related articles provided by PubMed. From the lists, only case-control studies that detected EBV in tissue samples were selected. In order to control for the heterogeneity among studies, subgroup analysis and meta-regression were performed.

Results: In the 33 case-control results with adjacent non-cancer tissue, the total number of test samples in the case and control groups was 5280 and 4962, respectively. In the 14 case-control results with normal tissue, the total number of test samples in case and control groups was 1393 and 945, respectively. Upon meta-regression, the type of control tissue was found to be a statistically significant variable with regard to heterogeneity. When the control tissue was normal tissue of healthy individuals, the SOR was 3.41 (95\% Cl, 1.78 to 6.51 ; I-squared, $65.5 \%)$.

Conclusions: The results of the present study support the argument that EBV infection increases the risk of gastric cancer. In the future, age-matched and sex-matched case-control studies should be conducted.

Key words: Gastric neoplasms, Risk factor, Epstein-Barr virus, Meta-analysis

\section{INTRODUCTION}

Globally, gastric cancer is the primary cancer that has the third highest mortality rate [1]. Gastric cancer is the second

Received: November 27, 2015 Accepted: February 1, 2016

Corresponding author: Jong-Myon Bae, MD, PhD

102 Jejudaehak-ro, Jeju 63243, Korea

Tel: +82-64-755-5567, Fax: +82-64-725-2593

E-mail: jmbae@jejunu.ac.kr

This is an Open Access article distributed under the terms of the Creative Commons Attribution Non-Commercial License (http://creativecommons.org/licenses/bync/3.0/) which permits unrestricted non-commercial use, distribution, and reproduction in any medium, provided the original work is properly cited. most common cancer in Koreans [2] as well, and it is considered to be caused by a complex association between various environmental and genetic factors [3,4]. In particular, understanding Epstein-Barr virus (EBV)-associated gastric cancer (EBVaGC), along with Helicobacter pylori, is important in prevention and management of gastric cancer [5-7].

EBV is 'the first human tumor virus' [8] and is currently categorized as a group-1 carcinogen due to its association with various cancers, such as nasopharyngeal carcinoma $[9,10]$. Starting with the study of Burke et al. [11] in 1990 that reported the discovery of EBV DNA in gastric cancer tissue, evidence supporting the fact that EBV is a risk factor for gastric cancer has been accumulating [12]. Accordingly, "the Cancer Genome At- 
las Research Network" [13] suggested a subtype called 'gastric cancer positive for EBV' in 2014.

The mechanism through which EBV causes gastric cancer is being established [13-15]; moreover, various systematic reviews on the detection rate of EBV in gastric cancer tissue $[3,16-$ $18]$ and the prognosis of gastric cancer according to EBV infection [19-21] have been published. However, in order to prove that a certain virus causes cancer, case-control studies are required [22]. Chen et al. [7] provided a comprehensive summary of case-control studies published until September 14, 2014. However, the authors did not perform a meta-analysis to calculate the summary odds ratio (SOR) and 95\% confidence interval (Cl) due to heterogeneity among studies.

The SOR corresponds to the 'strength of association,' which is a standard for causality judgment, and it is also a fundamental statistical value in investigation of the gastric cancer risk associated with EBV infection. In a meta-analysis in which the SOR is calculated, a random effects model, subgroup analysis, and meta-regression are applied in order to control for heterogeneity [23-25]. Through this study, we aim to calculate the SOR of gastric cancer risk according to EBV infection, by applying a meta-analysis with meta-regression, which controls for heterogeneity, on previous systematic review results.

\section{METHODS}

\section{Related Literature Search and Selection}

The systematic review of Chen et al. [7] on EBV and gastric cancer encompassed studies published until September 14, 2014, and did not conduct a meta-analysis. Thus we decided to include studies that were published until October 2015. Since the list of studies was already well-established, a hand search strategy, rather than an electronic search strategy, was employed [26-28]. In other words, references provided by Chen et al. [7] were analyzed, and lists of "cited articles" and "similar articles" provided by PubMed (www.ncbi.nlm.nih.gov/pubmed) for each article were also considered for inclusion.

In selecting studies for analysis, studies that conducted serologic tests on blood samples were excluded even though they were included in Chen et al. [7]. The reason is that EBVaGC is defined as a cancer in which EBV is detected in gastric cancer tissues $[6,18]$. Therefore, only case-control studies that used tissue as testing samples were included in the study. These comparative studies were divided into those using adjacent noncancer tissue (ANT) as the control tissue and those using nor- mal tissue (NT). For final selection, the following three exclusion criteria were first applied based on the titles and abstracts of the studies: experimental studies, expert reviews or systematic reviews, and case series studies. For the remaining casecontrol studies, the following four exclusion criteria were additionally applied: when no information on EBV detection was provided, when no subject in the patient and control groups was positive for EBV, when blood samples were used instead of tissue samples, and when duplicate samples were reported. Studies were considered to be duplicated when the authors' affiliations, their names, and the sources of cases were identical, and studies with higher numbers of samples were selected among the duplicate studies. The remaining case-control studies after the application of the seven aforementioned exclusion criteria were selected as the final studies for investigation.

\section{Statistical Analysis}

Application of exclusion criteria and investigation of EBVrelated information-the number of tests and the number of positive diagnoses of EBV in each of the case and control groups, nationality of subjects, analysis method, and type of control tissue-were performed by two researchers. Using the number of positive and negative diagnoses of EBV in each case and control group, the odds ratio (OR) and $95 \% \mathrm{Cl}$ were calculated for each study. Studies were categorized into four regions: Far East Asia, Middle East Asia, Europe, and the Americas. The analysis methods of the studies were divided into in situ hybridization (ISH) and polymerase chain reaction (PCR); moreover, the type of control tissue was divided into ANT and NT. Based on the two analysis methods and the two types of control tissue, studies were classified into four categories. In addition, studies were divided into pre-1999 and post-2000 groups based on year of publication. Heterogeneity among studies was assessed in a meta-analysis based on I-squared values (\%), and the SOR and $95 \% \mathrm{Cl}$ according to random effects models were calculated first. Among four variables-geographical area, analysis method, type of control tissue, and year of publication - that resulted in heterogeneity across studies, a metaregression analysis was conducted using the restricted maximum likelihood method [24]. In order to examine publication bias, Egger's test for small-study effects was conducted [25]. The level of statistical significance was set at 5\%, and Stata version 14 (StataCorp, College Station, TX, USA) was used for statistical analyses. 
Papers retrieved from databases $=372$

- From reference list of the systematic review by Chen et al. [7] $=48$

- Cited or related articles from PubMed $=324$

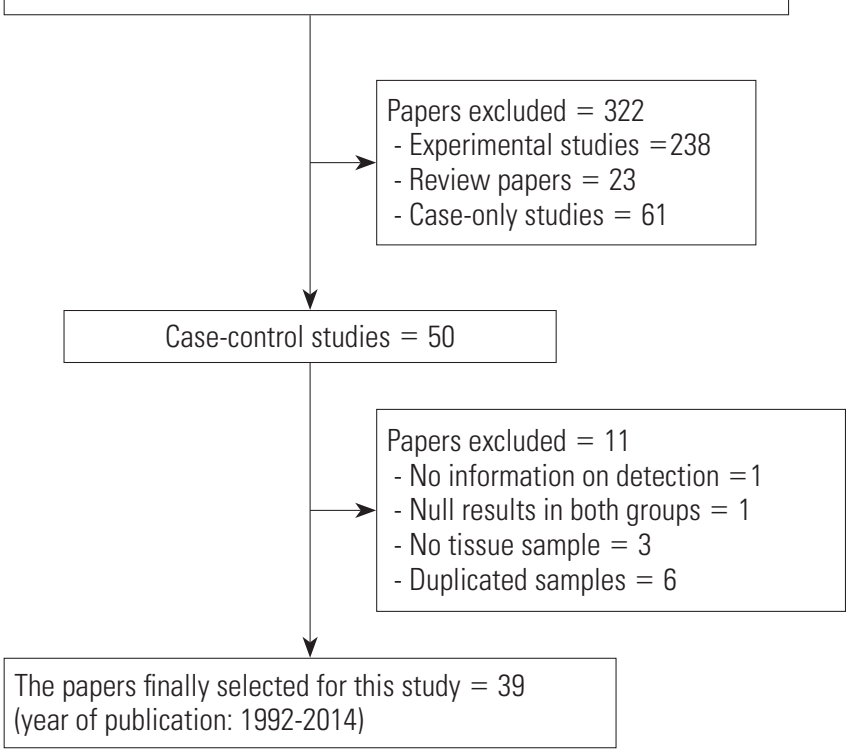

Figure 1. Flow chart of article selection.

\section{RESULTS}

Figure 1 shows the flow chart of article selection for final analysis. A list of 48 references from the selected studies in the systematic review of Chen et al. [7], and of 324 cited or related articles from PubMed, was compiled. When the selection criteria were applied to these 372 studies, 50 case-control studies were selected. Among these 50 studies, (1) one study that did not provide the EBV detection rate [29], (2) one study in which EBV was not detected in both patient and control groups [30], (3) three studies that used blood samples instead of tissue samples [31-33], and (4) six studies that used duplicate samples [34-39] were excluded. Specifically, Imai et al. [40] was selected instead of Tokunaga et al. [34], and Galetsky et al. [41] instead of 35. Gurtsevich et al. [35]. Ishii et al. [42] was selected instead of Yanai et al. [36], and Wang et al. [43] instead of Luo et al. [37]. Moreover, among the three studies by Saxena et al. [44], Shukla et al. [38,39], Saxena et al. [44] was selected, as it had the highest number of samples.

Through the aforementioned exclusion process, a total of 39 studies were selected for meta-analysis [38,40-77]. Among the 39 studies, a paper published in 2014 by de Souza et al. [76], which was not included in Chen et al. [7], was added to the present study based on our hand search. Table 1 shows the na- tionality of subjects and EBV sample test results in the final 39 case-control studies. In the 33 case-control results with ANT, the total number of test samples in the case and control groups was 5280 and 4962, respectively. Meanwhile, in the 14 casecontrol results with NT, the total number of test samples in the case and control groups was 1393 and 945, respectively. When a meta-analysis with a random effects model was applied to these 39 case-control studies, the risk of gastric cancer (SOR) according to positive detection of EBV exhibited a 10. The 10-fold increase ( $95 \% \mathrm{Cl}, 5.89$ to 17.29 ; I-squared, 65.3\%) (Table 2). When sorted by region, there were twenty studies in Far East Asia, four studies in Middle East Asia, six studies in Europe, and nine studies in the Americas, with the highest risk of gastric cancer associated with EBV infection in Far East Asia (SOR, $14.28 ; 95 \% \mathrm{Cl}, 6.58$ to 30.98 ; I-squared, $63.5 \%$ ), and no statistically significant risk found in Europe (SOR, $6.09 ; 95 \% \mathrm{Cl}, 0.66$ to 56.58; I-squared, 73.8\%) (Figure 2). The SOR did not differ significantly between the two groups of publication periods. Although the I-squared value decreased to $40.4 \%$ in studies published after 2000, a small-study effect was still present as the $p$ value of Egger's test was 0.019 .

Upon classification of the 39 studies according to type of control tissue and analysis method, 47 datasets were formulated because some studies used two types of control tissue or two kinds of analysis method (Figure 3). There were 31 ISH datasets and 16 PCR datasets based on the analysis method, and there were 33 ANT datasets and 14 NT datasets based on type of control tissue. The SOR of each of the two analysis methods and the two types of control tissue showed statistical significance, and the lowest level of risk was observed in the NT group (SOR, 3.41; $95 \% \mathrm{Cl}, 1.78$ to 6.51 ; I-squared, $65.5 \%$ ) (Table 2). Moreover, in Egger's test, no small-study effect was observed in the PCR and NT groups. When analysis methods and types of control tissues were analyzed simultaneously, nine datasets in which PCR was conducted on NT control tissues still had a statistically significant SOR (SOR, 3.72; $95 \% \mathrm{Cl}, 1.85$ to 7.48; I-squared, 58.6\%).

As I-squared values over $50 \%$ were observed in subgroup analysis by geographical area, analysis method, type of control tissue, and year of publication (Table 2), a meta-regression analysis was conducted on these four variables. In the meta-regression analysis of the 47 datasets, type of control tissue $(p=0.002)$ was found to be the variable that produced heterogeneity among studies, while the adjusted R-squared in the betweenstudy variance was $17.89 \%$ (Table 3 ). 
Table 1. Summary of the 39 selected case-control studies with detection of Epstein-Barr virus infection

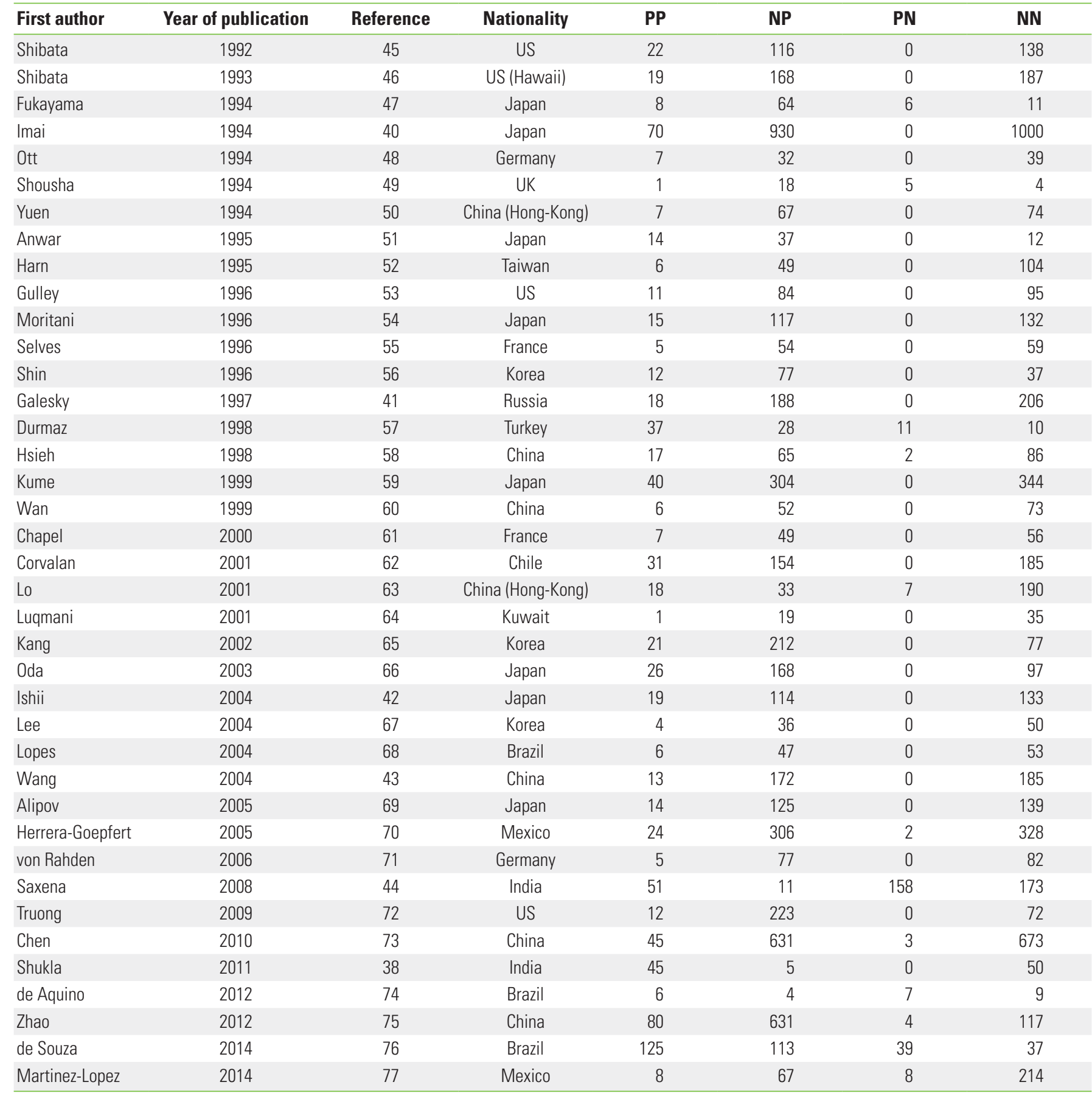

NN, normal negative; NP, normal positive; PN, patient negative; PP, patient positive.

\section{Discussion}

Based on the results of a meta-regression analysis showing that heterogeneity stemmed from type of control tissue, ANT and NT should be interpreted separately. However, if we also consider the results of Egger's test, which showed that a small- study effect was present in ANT, but not in NT, the SOR calculated from the 14 studies that used NT can be seen as a summary statistic that overcame heterogeneity. Therefore, we can conclude that the risk (SOR) of gastric cancer associated with EBV infection, which was $3.41(95 \% \mathrm{Cl}, 1.78$ to 6.51 ; I-squared, $65.5 \%)$, was statistically significant. 
Table 2. Sub-group analyses and sensitivity analyses by type of tissue and global area

\begin{tabular}{|c|c|c|c|c|c|}
\hline Conditions & $\begin{array}{l}\text { No. of articles } \\
\text { [datasets] }\end{array}$ & Reference & I-squared (\%) & SOR $[95 \%$ CI $]$ & $\begin{array}{c}p \text {-value of bias } \\
\text { (Egger's test) }\end{array}$ \\
\hline All & 39 & $38,40-77$ & 65.3 & $10.10[5.89,17.29]$ & 0.003 \\
\hline \multicolumn{6}{|l|}{ Area } \\
\hline Far East Asia & 20 & $40,42,43,46,47,50-52,54,56,58-60,63,65-67,69,73,75$ & 63.5 & $14.28[6.58,30.98]$ & 0.03 \\
\hline Middle East Asia & 4 & $38,44,57,64$ & 84.2 & $8.31[1.35,51.12]$ & 0.52 \\
\hline Europe & 6 & $41,48,49,55,61,71$ & 73.8 & $6.09[0.66,56.58]$ & 0.004 \\
\hline The Americas & 9 & $45,53,62,68,70,72,74,76,77$ & 39.8 & $7.04[3.05,16.21]$ & 0.04 \\
\hline \multicolumn{6}{|l|}{ Year of publication } \\
\hline-1999 & 18 & $40,41,45-60$ & 76.3 & $10.36[3.43,31.31]$ & 0.002 \\
\hline $2000-$ & 21 & $38,42-44,60-77$ & 40.4 & $9.42[5.67,15.66]$ & 0.02 \\
\hline Methods & [47] & & 70.3 & $8.62[5.12,14.49]$ & $<0.001$ \\
\hline ISH & [31] & $\begin{array}{l}40-43,45,47-50,52-56,59-62 \\
64-66,68-73,76\end{array}$ & 72.4 & $10.69[5.00,22.87]$ & $<0.001$ \\
\hline PCR & [16] & $38,44,46,51,57,58,63,66,67,74,75,77$ & 66.6 & $6.22[3.06,12.62]$ & 0.19 \\
\hline \multicolumn{6}{|l|}{ Control } \\
\hline ANT & [33] & $38,40-43,45-50,52-55,58-62,64-74,77$ & 65.0 & $14.03[6.85,28.74]$ & 0.007 \\
\hline NT & [14] & $44,51,52,56-58,63,66,67,74,75,77$ & 65.5 & $3.41[1.78,6.51]$ & 0.19 \\
\hline \multicolumn{6}{|l|}{ Method \& control } \\
\hline ISH \& ANT & [26] & $40-43,45,47-50,52-55,59-62,64-66,68-73$ & 64.7 & $13.22[5.62,30.04]$ & 0.03 \\
\hline ISH \& NT & [5] & $52,56,60,64,76$ & 34.1 & $2.56[0.79,8.33]$ & 0.04 \\
\hline PCR \& ANT & [7] & $38,46,58,66,67,74,77$ & 70.2 & $17.77[3.58,88.26]$ & 0.14 \\
\hline PCR \& NT & [9] & $44,51,57,58,63,67,74,75,77$ & 58.6 & $3.72[1.85,7.48]$ & 0.97 \\
\hline
\end{tabular}

SOR, summary odds ratio; Cl, confidence intervals; ISH, in situ hybridization; PCR, polymerase chain reaction; ANT, adjacent normal stomach tissue away from tumor; NT, normal tissue.

Although ISH is the gold standard test used to detect EBV infection [6], the SOR of the five studies that conducted ISH on NT samples did not possess statistical significance (SOR, 2.56; $95 \% \mathrm{Cl}, 0.79$ to 8.33 ; I-squared, $34.1 \%$ ); in contrast, the SOR of the nine studies that conducted PCR on NT samples showed statistical significance (SOR, 3.72; $95 \% \mathrm{Cl}, 1.85$ to 7.48 ; I-squared, $58.6 \%)$. Since the confidence interval is wider in the NT \& ISH group, the level of accuracy in the detection method by the sampling period should be taken into consideration.

The risk of gastric cancer showed regional variation in this study, and the highest risk was observed in Far East Asia, which has a high incidence of gastric cancer. Such a result also supports the causality of the connection we found since there is a positive correlation between the incidence and level of risk. However, our result contradicts that of Lee et al. [18], who reported that EBV infection is not associated with the incidence of gastric cancer in Asians upon the analysis of $48 \mathrm{ISH}$ studies published up to December 2007 (SOR, 0.698; 95\% Cl, 0.46 to 1.05). However, several case series studies were included in the investigation of Lee et al. [18], and we found calculation errors in several $O R$ values in that study; therefore, due to these errors in Lee et al., it is difficult to interpret our results in comparison to those of Lee et al. In addition, although Murphy et al. [3] reported that the prevalence of EBV-positive gastric cancer did not differ according to geographical region, the study of Murphy et al. was focused on prevalence, so it was of limited value in a comparison to our findings.

In this systematic review, a hand search, rather than electronic search, was prioritized because an existing reference list from the systematic review of Chen et al. [7] published without a meta-analysis was used to identify the bulk of the studies we analyzed. We extended the search to include studies published through October 2015, and thus included an additional study not in the existing systematic review-that of de Souza et al. [76], which was published on October 15, 2014. In contrast, no additional study published until September 2014 was included, and we were able to confirm that the study of Chen et al. [7] was indeed 'the first comprehensive systematic 


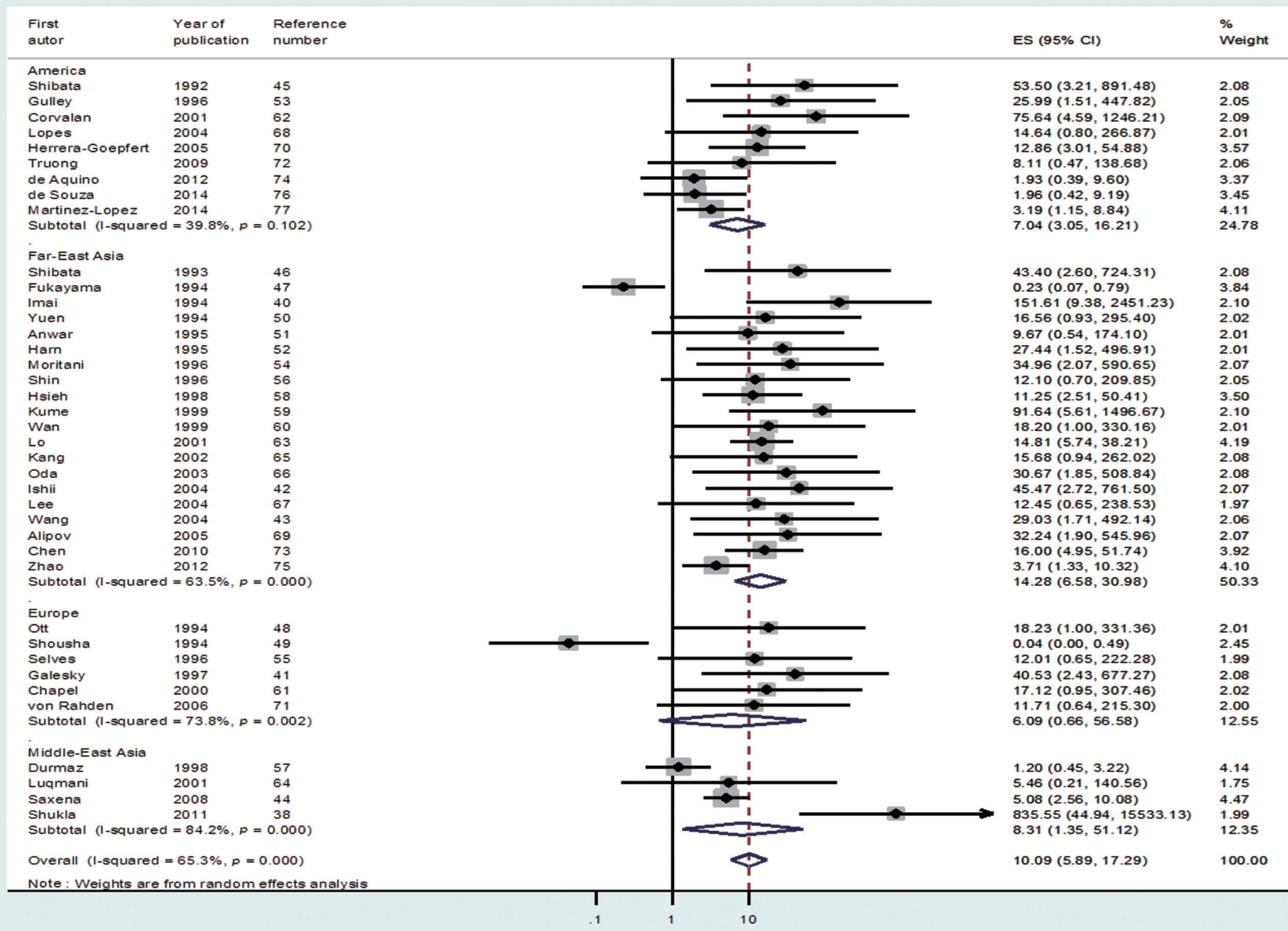

Figure 2. A forest plot of the summary effect size (ES = odds ratio) using a random effects model by geographical area in 39 casecontrol studies.

review' of this subject. The list of 39 studies selected in the present study should play an important role in an updated metaanalysis in near future.

Limitations of the present study include the fact that regional differences cannot be interpreted as ethnic differences [53] since immigrants could have been included in classifications according to nationality $[46,62]$. Therefore, future studies on genetic sensitivity by ethnicity should be conducted. Second, the present study could not take into consideration sex, age, $H$. pylori infection, or type of tissue $[18,76]$, as it was difficult to obtain related information about the control groups. Moreover, since many studies-including a study that used paraffin-embedded tissue for the gastric cancer tissue but used endoscopic biopsy for control tissue-used multiple types of tissues, it was also difficult to control for the variation in type of tissue. Finally, the result of an individually matching case-control study should be presented as a matched OR. The present study had to estimate the OR based on frequency because it was a systematic review. In the future, case-control studies that match gastric cancer tissues and healthy individuals' control tissues according to sex and age should be conducted, and pooled casecontrol studies that gather previous study reports and adjust for sex and age are also recommended.

In conclusion, the results of a meta-analysis that adjusted for heterogeneity among 39 case-control studies support the argument that EBV infection increases the risk of gastric cancer. Further analyses should be conducted separately for different types of control tissues. Moreover, in order to obtain a more accurate SOR, case-control studies that match more strictly by sex, age, and type of tissue are required. 


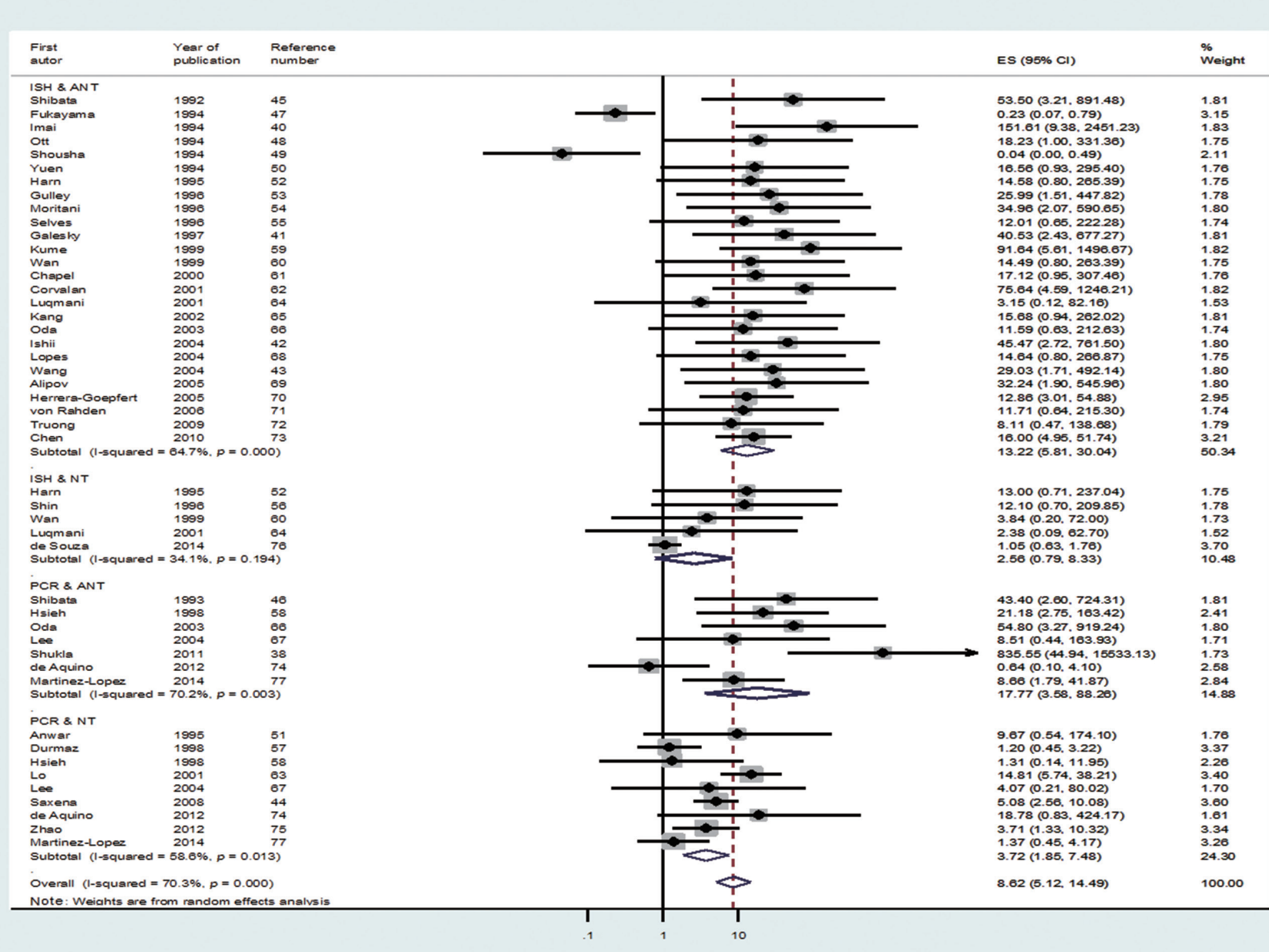

Figure 3. The forest plot of summary effect size (ES = odds ratio) using a random effect model by types of control tissues and analysis methods in 47 datasets. ANT, adjacent normal stomach tissue away from tumor; ISH, in situ hybridization; NT; normal tissue; PCR, polymerase chain reaction.

Table 3. Results of meta-regression

Meta-regression

Residual maximum likelihood estimate of between-study variance

$\%$ residual variation due to heterogeneity

Proportion of between-study variance explained

Joint test for all covariates

With Knapp-Hartung modification
No. of observation $=47$

tau2 $=1.534$

I-squared res $=58.35 \%$ Adjusted R-squared $=17.89 \%$

Model $F(4,42)=2.18$

Prob $>F=0.0873$

\begin{tabular}{lcccccc}
\hline logor & Coefficient & Standard error & $\mathbf{t}$ & $\boldsymbol{p}>|\mathbf{t}|$ & \multicolumn{2}{c}{ 95\% confidence interval } \\
\hline nat & -0.316648 & 0.2057256 & -1.54 & 0.131 & -0.731819 & 0.098523 \\
py & 0.4750994 & 0.5462101 & 0.87 & 0.389 & -0.6271973 & 1.577396 \\
mt & 0.0841765 & 0.592198 & 0.14 & 0.888 & -1.110928 & 1.27928 \\
co & -1.432607 & 0.5940019 & -2.41 & 0.020 & -2.631352 & -0.233863 \\
_cons & 3.865909 & 1.147969 & 3.37 & 0.002 & 1.549213 & 6.182604 \\
\hline
\end{tabular}


hybridization, 2 = polymerase chain reaction); co, types of control tissue (1=adjacent normal tissue away from tumor; 2 =normal tissue from healthy control). 


\section{CONFLICT OF INTEREST}

The authors have no conflicts of interest associated with the material presented in this paper.

\section{ORCID}

Jong-Myon Bae http://orcid.org/0000-0003-3080-7852

Eun Hee Kim http://orcid.org/0000-0002-1065-1080

\section{REFERENCES}

1. Ferlay J, Shin HR, Bray F, Forman D, Mathers C, Parkin DM. Estimates of worldwide burden of cancer in 2008: GLOBOCAN 2008. Int J Cancer 2010;127(12):2893-2917.

2. Jung KW, Won YJ, Kong HJ, Oh CM, Cho H, Lee DH, et al. Cancer statistics in Korea: incidence, mortality, survival, and prevalence in 2012. Cancer Res Treat 2015;47(2):127-141.

3. Murphy G, Pfeiffer R, Camargo MC, Rabkin CS. Meta-analysis shows that prevalence of Epstein-Barr virus-positive gastric cancer differs based on sex and anatomic location. Gastroenterology 2009;137(3):824-833.

4. Shi J, Qu YP, Hou P. Pathogenetic mechanisms in gastric cancer. World J Gastroenterol 2014;20(38):13804-13819.

5. Wroblewski LE, Peek RM Jr. Helicobacter pylori in gastric carcinogenesis: mechanisms. Gastroenterol Clin North Am 2013; 42(2):285-298.

6. Shinozaki-Ushiku A, Kunita A, Fukayama M. Update on EpsteinBarr virus and gastric cancer (review). Int J Oncol 2015; 46(4): 1421-1434.

7. Chen XZ, Chen H, Castro FA, Hu JK, Brenner H. Epstein-Barr virus infection and gastric cancer: a systematic review. Medicine (Baltimore) 2015;94(20):e792.

8. Javier RT, Butel JS. The history of tumor virology. Cancer Res 2008;68(19):7693-7706.

9. Camargo MC, Murphy G, Koriyama C, Pfeiffer RM, Kim WH, Herrera-Goepfert R, et al. Determinants of Epstein-Barr viruspositive gastric cancer: an international pooled analysis. $\mathrm{Br} J$ Cancer 2011;105(1):38-43.

10. International Agency for Research on Cancer (IARC). Agents classified by the IARC monographs, volumes 1-112 [cited 2015 Nov 12]. Available from: http://monographs.iarc.fr/ENG/Classification/ClassificationsGroupOrder.pdf.

11. Burke AP, Yen TS, Shekitka KM, Sobin LH. Lymphoepithelial carcinoma of the stomach with Epstein-Barr virus demonstrated by polymerase chain reaction. Mod Pathol 1990;3(3):377-380.

12. Akiba S, Koriyama C, Herrera-Goepfert R, Eizuru Y. EpsteinBarr virus associated gastric carcinoma: epidemiological and clinicopathological features. Cancer Sci 2008;99(2):195-201.

13. Cancer Genome Atlas Research Network. Comprehensive molecular characterization of gastric adenocarcinoma. Nature 2014:513(7517):202-209.

14. Fukayama M, Hino R, Uozaki H. Epstein-Barr virus and gastric carcinoma: virus-host interactions leading to carcinoma. Cancer Sci 2008:99(9):1726-1733.

15. Uozaki H, Fukayama M. Epstein-Barr virus and gastric carcinoma--viral carcinogenesis through epigenetic mechanisms. Int J Clin Exp Pathol 2008;1(3):198-216.

16. Li S, Du H, Wang Z, Zhou L, Zhao X, Zeng Y. Meta-analysis of the relationship between Epstein-Barr virus infection and clinicopathological features of patients with gastric carcinoma. Sci China Life Sci 2010;53(4):524-530.

17. Sousa H, Pinto-Correia AL, Medeiros R, Dinis-Ribeiro M. Epstein-Barr virus is associated with gastric carcinoma: the question is what is the significance? World J Gastroenterol 2008; 14(27):4347-4351.

18. Lee JH, Kim SH, Han SH, An JS, Lee ES, Kim YS. Clinicopathological and molecular characteristics of Epstein-Barr virus-associated gastric carcinoma: a meta-analysis. J Gastroenterol Hepatol 2009;24(3):354-365.

19. Zong L, Seto Y. CpG island methylator phenotype, Helicobacter pylori, Epstein-Barr virus, and microsatellite instability and prognosis in gastric cancer: a systematic review and meta-analysis. PLoS One 2014;9(1):e86097.

20. Chen YP, Zhang WN, Chen L, Tang LL, Mao YP, Li WF, et al. Effect of latent membrane protein 1 expression on overall survival in Epstein-Barr virus-associated cancers: a literature-based metaanalysis. Oncotarget 2015;6(30):29311-29323.

21. Liu X, Liu J, Qiu H, Kong P, Chen S, Li W, et al. Prognostic significance of Epstein-Barr virus infection in gastric cancer: a metaanalysis. BMC Cancer 2015;15:782.

22. Liang W, Tian H. Hypothetic association between human papillomavirus infection and breast carcinoma. Med Hypotheses 2008;70(2):305-307.

23. Sterne JA, Harbord RM. Funnel plots in meta-analysis. Stata J 2004;4(2):127-141

24. Harbord RM, Higgins JP. Meta-regression in Stata. Stata J 2008:8(4):493-519.

25. Harbord RM, Egger M, Sterne JA. A modified test for smallstudy effects in meta-analyses of controlled trials with binary 
endpoints. Stat Med 2006;25(20):3443-3457.

26. Bae JM. Narrative reviews. Epidemiol Health 2014;36:e2014018.

27. Bae JM. Human papillomavirus 16 infection as a potential risk factor for prostate cancer: an adaptive meta-analysis. Epidemiol Health 2015;37:e2015005.

28. Bae JM, Kim EH. Hormone replacement therapy and risk of breast cancer in Korean women: a quantitative systematic review. J Prev Med Public Health 2015;48(5):225-230.

29. Sakuma K, Uozaki H, Chong JM, Hironaka M, Sudo M, Ushiku T, et al. Cancer risk to the gastric corpus in Japanese, its correlation with interleukin-1 beta gene polymorphism (+3953*T) and Epstein-Barr virus infection. Int J Cancer 2005;115(1):93-97.

30. Yuan XY, Wang MY, Wang XY, Chang AY, Li J. Non-detection of Epstein-Barr virus and Human Papillomavirus in a region of high gastric cancer risk indicates a lack of a role for these viruses in gastric carcinomas. Genet Mol Biol 2013;36(2):183-184.

31. Koshiol J, Qiao YL, Mark SD, Dawsey SM, Abnet CC, Kamangar F, et al. Epstein-Barr virus serology and gastric cancer incidence and survival. Br J Cancer 2007;97(11):1567-1569.

32. Kim Y, Shin A, Gwack J, Ko KP, Kim CS, Park SK, et al. EpsteinBarr virus antibody level and gastric cancer risk in Korea: a nested case-control study. Br J Cancer 2009;101(3):526-529.

33. Schetter AJ, You WC, Lennette ET, Gail MT, Rabkin CS. Association of Epstein-Barr virus antibody levels with precancerous gastric lesions in a high-risk cohort. Cancer Sci 2008; 99(2):350354.

34. Tokunaga M, Land CE, Uemura Y, Tokudome T, Tanaka S, Sato E. Epstein-Barr virus in gastric carcinoma. Am J Pathol 1993; 143(5):1250-1254.

35. Gurtsevich VE, Galetskiĭ SA, Nered SN, Novikova EV, lakovleva LS, Land ChE, et al. Detection and characterization of gastric carcinoma associated with Epstein-Barr herpes virus. Vestn Ross Akad Med Nauk 1999;(3):56-59 (Russian).

36. Yanai H, Nishikawa J, Mizugaki Y, Shimizu N, Takada K, Matsusaki K, et al. Endoscopic and pathologic features of Epstein-Barr virus-associated gastric carcinoma. Gastrointest Endosc 1997; 45(3):236-342.

37. Luo B, Wang Y, Wang XF, Liang $H$, Yan LP, Huang BH, et al. Expression of Epstein-Barr virus genes in EBV-associated gastric carcinomas. World J Gastroenterol 2005;11(5):629-633.

38. Shukla SK, Prasad KN, Tripathi A, Singh A, Saxena A, Ghoshal UC, et al. Epstein-Barr virus DNA load and its association with Helicobacter pylori infection in gastroduodenal diseases. Braz $J$ Infect Dis 2011;15(6):583-590.

39. Shukla SK, Prasad KN, Tripathi A, Ghoshal UC, Krishnani N, Hu- sain N. Expression profile of latent and lytic transcripts of epstein-barr virus in patients with gastroduodenal diseases: a study from northern India. J Med Virol 2012;84(8):1289-1297.

40. Imai S, Koizumi S, Sugiura M, Tokunaga M, Uemura Y, Yamamoto N, et al. Gastric carcinoma: monoclonal epithelial malignant cells expressing Epstein-Barr virus latent infection protein. Proc Natl Acad Sci U S A 1994;91(19):9131-9135.

41. Galetsky SA, Tsvetnov VV, Land CE, Afanasieva TA, Petrovichev NN, Gurtsevitch VE, et al. Epstein-Barr-virus-associated gastric cancer in Russia. Int J Cancer 1997;73(6):786-789.

42. Ishii HH, Gobe GC, Yoneyama J, Mukaide M, Ebihara Y. Role of p53, apoptosis, and cell proliferation in early stage EpsteinBarr virus positive and negative gastric carcinomas. J Clin Pathol 2004;57(12):1306-1311.

43. Wang Y, Luo B, Zhao P, Huang BH. Expression of Epstein-Barr virus genes in EBV-associated gastric carcinoma. Ai Zheng 2004;23(7):782-787 (Chinese).

44. Saxena A, Nath Prasad K, Chand Ghoshal U, Krishnani N, Roshan Bhagat M, Husain N. Association of Helicobacter pylori and Epstein-Barr virus with gastric cancer and peptic ulcer disease. Scand J Gastroenterol 2008;43(6):669-674.

45. Shibata D, Weiss LM. Epstein-Barr virus-associated gastric adenocarcinoma. Am J Pathol 1992;140(4):769-774.

46. Shibata D, Hawes D, Stemmermann GN, Weiss LM. EpsteinBarr virus-associated gastric adenocarcinoma among Japanese Americans in Hawaii. Cancer Epidemiol Biomarkers Prev 1993; 2(3):213-217.

47. Fukayama M, Hayashi Y, Iwasaki Y, Chong J, Ooba T, Takizawa T, et al. Epstein-Barr virus-associated gastric carcinoma and Epstein-Barr virus infection of the stomach. Lab Invest 1994; 71(1):73-81.

48. Ott G, Kirchner T, Müller-Hermelink HK. Monoclonal EpsteinBarr virus genomes but lack of EBV-related protein expression in different types of gastric carcinoma. Histopathology 1994; 25(4):323-329.

49. Shousha S, Luqmani YA. Epstein-Barr virus in gastric carcinoma and adjacent normal gastric and duodenal mucosa. J Clin Pathol 1994;47(8):695-698.

50. Yuen ST, Chung LP, Leung SY, Luk IS, Chan SY, Ho J. In situ detection of Epstein-Barr virus in gastric and colorectal adenocarcinomas. Am J Surg Pathol 1994;18(11):1158-1163.

51. Anwar K, Nakakuki K, Imai H, Inuzuka M. Infection of human papillomavirus (hpv) and Epstein-Barr-virus (EBV) and p53 overexpression in human gastric-carcinoma. Int J Oncol 1995; 7(2):391-397. 
52. Harn HJ, Chang JY, Wang MW, Ho LI, Lee HS, Chiang JH, et al. Epstein-Barr virus-associated gastric adenocarcinoma in Taiwan. Hum Pathol 1995;26(3):267-271.

53. Gulley ML, Pulitzer DR, Eagan PA, Schneider BG. Epstein-Barr virus infection is an early event in gastric carcinogenesis and is independent of bcl-2 expression and p53 accumulation. Hum Pathol 1996;27(1):20-27.

54. Moritani S, Kushima R, Sugihara H, Hattori T. Phenotypic characteristics of Epstein-Barr-virus-associated gastric carcinomas. J Cancer Res Clin Oncol 1996;122(12):750-756.

55. Simon G, Francescutti C, Brusin S, Rosa F. Variation in drug prescription costs and general practitioners in an area of North-East Italy. The use of current data. Epidemiol Prev 1994;18(61):224-229 (Italian).

56. Shin WS, Kang MW, Kang JH, Choi MK, Ahn BM, Kim JK, et al. Epstein-Barr virus-associated gastric adenocarcinomas among Koreans. Am J Clin Pathol 1996;105(2):174-181.

57. Durmaz R, Aydin A, Köroglu M, Durmaz B, Ciralik H. Investigation of the relationship between Epstein-Barr virus and ordinary gastric carcinoma using the nested polymerase chain reaction. Acta Virol 1998;42(6):359-363.

58. Hsieh LL, Lin PJ, Chen TC, Ou JT. Frequency of Epstein-Barr virus-associated gastric adenocarcinoma in Taiwan. Cancer Lett 1998;129(2):125-129.

59. Kume T, Oshima K, Shinohara T, Takeo H, Yamashita Y, Shirakusa T, et al. Low rate of apoptosis and overexpression of bcl-2 in Epstein-Barr virus-associated gastric carcinoma. Histopathology 1999;34(6):502-509.

60. Wan R, Gao MQ, Gao LY, Chen BF, Cai QK. In situ detection of Epstein Barr virus in gastric carcinoma tissue in China highrisk area. World J Gastroenterol 1999;5(6):531-532.

61. Chapel F, Fabiani B, Davi F, Raphael M, Tepper M, Champault G, et al. Epstein-Barr virus and gastric carcinoma in Western patients: comparison of pathological parameters and p53 expression in EBV-positive and negative tumours. Histopathology 2000;36(3):252-261.

62. Corvalan A, Koriyama C, Akiba S, Eizuru Y, Backhouse C, Palma $M$, et al. Epstein-Barr virus in gastric carcinoma is associated with location in the cardia and with a diffuse histology: a study in one area of Chile. Int J Cancer 2001;94(4):527-530.

63. Lo YM, Chan WY, Ng EK, Chan LY, Lai PB, Tam JS, et al. Circulating Epstein-Barr virus DNA in the serum of patients with gastric carcinoma. Clin Cancer Res 2001;7(7):1856-1859.

64. Luqmani YA, Linjawi SO, Shousha S. Detection of Epstein-Barr virus in gastrectomy specimens. Oncol Rep 2001;8(5):995-999.
65. Kang GH, Lee S, Kim WH, Lee HW, Kim JC, Rhyu MG, et al. Epstein-barr virus-positive gastric carcinoma demonstrates frequent aberrant methylation of multiple genes and constitutes CpG island methylator phenotype-positive gastric carcinoma. Am J Pathol 2002;160(3):787-794.

66. Oda K, Koda K, Takiguchi N, Nunomura M, Seike K, Miyazaki M. Detection of Epstein-Barr virus in gastric carcinoma cells and surrounding lymphocytes. Gastric Cancer 2003;6(3):173-178.

67. Lee MA, Hong YS, Kang JH, Lee KS, You JY, Lee KY, et al. Detection of Epstein-Barr virus by PCR and expression of LMP1, p53, CD44 in gastric cancer. Korean J Intern Med 2004;19(1):43-47.

68. Lopes LF, Bacchi MM, Elgui-de-Oliveira D, Zanati SG, Alvarenga $M$, Bacchi CE. Epstein-Barr virus infection and gastric carcinoma in São Paulo State, Brazil. Braz J Med Biol Res 2004; 37(11):17071712.

69. Alipov G, Nakayama T, Nakashima M, Wen CY, Niino D, Kondo $\mathrm{H}$, et al. Epstein-Barr virus-associated gastric carcinoma in Kazakhstan. World J Gastroenterol 2005;11(1):27-30.

70. Herrera-Goepfert R, Akiba S, Koriyama C, Ding S, Reyes E, Itoh $\mathrm{T}$, et al. Epstein-Barr virus-associated gastric carcinoma: evidence of age-dependence among a Mexican population. World J Gastroenterol 2005;11(39):6096-6103.

71. von Rahden BH, Langner C, Brücher BL, Stein HJ, Sarbia M. No association of primary adenocarcinomas of the small bowel with Epstein-Barr virus infection. Mol Carcinog 2006; 45(5):349-352.

72. Truong CD, Feng W, Li W, Khoury T, Li Q, Alrawi S, et al. Characteristics of Epstein-Barr virus-associated gastric cancer: a study of 235 cases at a comprehensive cancer center in U.S.A. J Exp Clin Cancer Res 2009;28:14.

73. Chen JN, Ding YG, Feng ZY, Li HG, He D, Du H, et al. Association of distinctive Epstein-Barr virus variants with gastric carcinoma in Guangzhou, southern China. J Med Virol 2010; 82(4):658-667.

74. de Aquino PF, Carvalho PC, da Gama Fischer JS, de Souza AQ, Viana JS, Chalub SR, et al. Epstein-Barr virus DNA associated with gastric adenocarcinoma and adjacent non-cancerous mucosa in patients from Manaus, Brazil. Genet Mol Res 2012; 11(4):4442-4446.

75. Zhao J, Jin H, Cheung KF, Tong JH, Zhang S, Go MY, et al. Zinc finger E-box binding factor 1 plays a central role in regulating Epstein-Barr virus (EBV) latent-lytic switch and acts as a therapeutic target in EBV-associated gastric cancer. Cancer 2012; 118(4):924-936.

76. de Souza CR, de Oliveira KS, Ferraz JJ, Leal MF, Calcagno DQ, 
Seabra AD, et al. Occurrence of Helicobacter pylori and Epstein-Barr virus infection in endoscopic and gastric cancer patients from Northern Brazil. BMC Gastroenterol 2014;14:179.
77. Weinstein SJ, Stolzenberg-Solomon R, Pietinen P, Taylor PR, Virtamo J, Albanes D. Dietary factors of one-carbon metabolism and prostate cancer risk. Am J Clin Nutr 2006;84(4):929-935. 